\title{
Principles for effective tobacco warning systems: the USA gets a failing grade
}

\author{
Garfield Mahood
}

The US Food and Drug Administration (FDA) has introduced its new tobacco warning system after 35 years of weak, stale warnings. And now, ostensibly due to the COVID-19 pandemic, the FDA has delayed the 'effective date' of the new warnings $^{1}$ until October 16, 2021. Superior warnings have been required on American products sold internationally for more than two decades. Despite the criticism below, the improved text, size and positioning of the new warnings will save thousands of lives. However, they offer little worth replicating elsewhere.

The critique that follows draws from my interest in tobacco warnings developed while heading Canada's Non-Smokers' Rights Association (NSRA) from 19762012. The NSRA led campaigns for Canada's landmark tobacco advertising ban (1988) and for global precedent-setting package warnings (1994 and 2001). These reforms triggered tobacco-related law reform around the world and undoubtedly led to the NSRA being cited in 2000 as the inaugural recipient of the American Cancer Society's international Luther L Terry Award in the 'Outstanding Organization' category.

Given this history with warnings, I believe that a strong tobacco product warning system incorporates at least five essential elements:

\section{UPHOLD THE TORT LAW STANDARD IN THE COMMON LAW}

Tort law requires manufacturers in the USA, Canada and other countries to warn both of the nature of the risks of their products and the magnitude of the danger caused. ${ }^{2}$ When designing tobacco warning systems, governments should not adopt a standard for warnings below what is considered acceptable in law for other products. Unfortunately, the USA has done precisely that.

Almost every warning system on the globe has a warning of lung cancer, but this key warning did not make the final list of American warnings. In contrast, Canada had two effective lung cancer warnings in the 2001 phase of its warnings. One

Correspondence to Mr Garfield Mahood, President Campaign for Justice on Tobacco Fraud, 196 MacPherson Avenue, Toronto, ON M5R 1W8, Canada; gmahood@justiceontobaccofraud.ca read 'WARNING CIGARETTES CAUSE LUNG CANCER'. The subtext spelled out the magnitude of the risk, ' $85 \%$ of lung cancers are caused by smoking; $80 \%$ of lung cancer victims die within 3 years.'

The US warning designed to warn of harm to children, 'WARNING: Tobacco smoke can harm your children', fails to explain the specific nature of risk to children that is suggested by a child using an oxygen mask, never mind the magnitude of danger to an asthmatic. Now, consider the text of the current Canadian warning that uses a similar picture to the one just mandated by the FDA, 'WARNING Your kids are sick of your smoking. Secondhand smoke causes more frequent and severe asthmatic attacks in children'. ${ }^{3}$

\section{PERSONALISE THE RISK}

Where possible, warnings are strengthened when they are personalised and have real people associated with the risk in question. Consider one of Canada's two Barb Tarbox lung cancer warnings, probably the most powerful to ever appear on Canadian packages (figure 1). After contracting lung cancer, Tarbox wanted to help teens stay away from tobacco addiction. The label reads 'WARNING This is what dying of lung cancer looks like. Barb Tarbox died at 42 of lung cancer caused by cigarettes.'

\section{USE WARNING TEXT CREATIVELY}

The choice of language in warnings is important beyond frank information about risks. Tobacco industry denormalisation (TID) wording in warnings is another important element not utilised by the FDA. To the extent possible, warning language should shift the responsibility for the tobacco epidemic away from individual behaviour, often started before the age of responsibility, toward corporate responsibility. ${ }^{4}$ TID language can subtly change attitudes and is associated with behaviour changes. ${ }^{5}$ The more smokers are reminded of the predatory role of tobacco companies in their addiction, the greater motivation that many will have to reconsider their involvement with the industry's products. ${ }^{6}$

Consider the FDA label, 'WARNING: Smoking can cause heart disease and strokes by clogging arteries'. This message implies that the individual smoker carries the responsibility for disease he or she contracts even if addiction is involved and the manufacturers failed to warn and to keep their product away from minors. The warning could have incorporated a TID component if it had read 'WARNING Cigarettes (or This product) cause(s) heart disease, strokes, disability and death by clogging arteries'. Changing 'smoking' to 'cigarettes' or 'This product' as with the Tarbox warning may seem trivial, even insignificant. However, a small language change like this when repeated over time on billions of packages goes a long way toward undoing the presumed legitimacy of the product and the industry.

\section{PASS THE TOBACCO INDUSTRY 'SCREAM TEST'}

Another key element in any effective warning system is the inclusion of warnings that pass 'the scream test' with tobacco manufacturers. For decades, the industry feared the addiction warning above all other warnings, undoubtedly because of its impact on litigation. Addiction warnings pass 'the scream test'. The US decision in 2020 to exclude an addiction message is inexplicable when addiction warnings first appeared on American brands on Canadian packages 25 years ago. $^{7}$

At least as far back as 1978, Big Tobacco was aware that the secondhand smoke (SHS) issue was a developing industry disaster. $^{8}$ To protect its market, it undertook major disinformation campaigns to forestall laws designed to protect non-smokers. ${ }^{9}$ Given the importance of this issue, one might have expected at least one strong SHS warning. However, 'WARNING: Tobacco smoke causes fatal lung disease in non-smokers', one of two SHS warnings just enacted, could have been strengthened. Had the warning drafters used 'secondhand smoke', the term in common usage, replaced the less understood word 'fatal' with the better understood ultimate risk, 'death', introduced the more emotive term 'cancer' and recognised other SHS disease risks, this uninspired warning might have read 'WARNING Secondhand smoke causes disability and death in non-smokers from cancer, heart and lung diseases'. It is common knowledge that the SHS issue has been and continues to be a major factor in the reduction of tobacco use in the USA and elsewhere. It seems incomprehensible then that the limited FDA warning about SHS was the best that the agency could produce. 


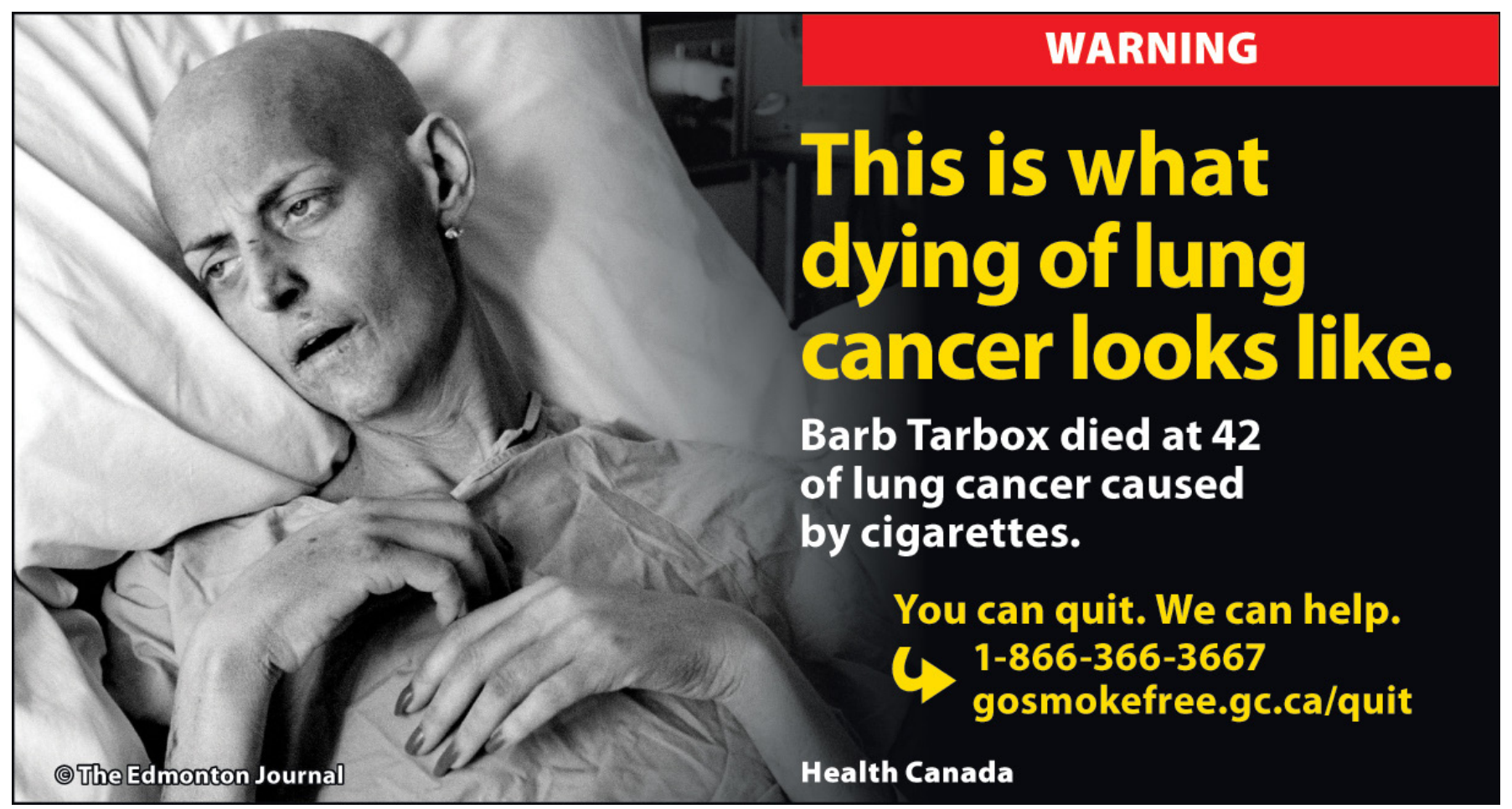

Figure 1 Canada's Barb Tarbox warning, 2012, showing personalisation of risk, tobacco industry denormalisation wording and a cessation message offering hope.

The FDA deserves credit for mandating a peripheral vascular disease warning but the text never mentions gangrene, a word that Canadian focus groups identified as having real power. This text might have been improved with 'WARNING GANGRENE This product reduces blood flow to your limbs. This causes gangrene and requires amputation.'

\section{OFFER HOPE}

The provision of anxiety-producing messages to prevent starting and to encourage cessation is the purpose of a warning system. However, the public health benefit from warnings will be increased when the smoker is offered hope and motivation to address their addiction. Canadian warnings since 2001 have included both interior and exterior cessation messages. Still, cessation text should not be allowed to overwhelm the risk messaging, the main purpose of any warning system.

The US warnings have a number of problems. Few have a serious magnitude of risk component. They do not include the TID element suggesting that the product in the package is the problem. 'Smoking', in all of the texts, keeps the responsibility for addiction largely on the victim. Problems with texts exist throughout. Few copywriters would weaken a message by putting important information in subordinate clauses, for example, 'which can require amputation' or 'which can cause erectile dysfunction'. Short, creative sentences are a key to effective communication. As well, the space mandated for these warnings is sufficient to accommodate more comprehensive texts. And a graphic flaw: why would the marker WARNING not be printed in red ink to underline the importance of the message?

The potential to improve the messages appears throughout. Consider, for example, 'Smoking causes type 2 diabetes, which raises blood sugar'. Many smokers would not understand the graphic if they had no experience with glucometers. The text fails to explain the risk associated with high blood sugar levels.

The label 'Smoking during pregnancy stunts fetal growth' is inadequate given the dangers involved. A more comprehensive warning was included in Canada's landmark system in 2001. 'WARNINGTOBACCO SMOKE HURTS BABIES. Tobacco use during pregnancy increases the risk of preterm birth. Babies born preterm are at an increased risk of infant death, illness and disability.'

The warning 'Smoking causes head and neck cancer' is also incomplete. It should include a frank magnitude-of-risk and denormalisation message. Such a label might have read 'This product causes head and neck cancers, pain, disfigurement and death.'
There are significant other textual and graphic flaws in the FDA system which are not addressed here, understandable due to space limitations.

In conclusion, as tobacco companies know, the package is a mini billboard that can potentially deliver billions of health warning impressions on and in packages worldwide every year. Package warnings can dwarf all of the pamphlets and online campaigns that health agencies and governments produce. Many countries do not have sufficient revenue to fund effective health education. For many, the most cost-effective, perfectly targeted health education strategy is messaging right on and in the package. Further, the messages on packages are viewed by children who are forming their opinions about cigarettes. With countless millions of packages viewed many times each day, effective package education systems continue to hold huge public health potential.

Given that an effective warning system on tobacco packaging can be the cornerstone of public education on tobacco in every country, health groups should press their governments to produce effective warnings and frequent revisions to prevent risk messaging from becoming stale. Health advocates should also counter the industry's continued lobbying to weaken warning messages when revisions are underway. In Canada, in 2012, a disinterested, heavily lobbied government enacted 
warnings that eliminated many of the features in the precedent-setting warning systems enacted in 1994 and 2001. ${ }^{10}$

Finally, health interests might review the WHO booklet 'Canada's Tobacco Package Label or Warning System: 'Telling the Truth' about Tobacco Product Risks' prepared for the Tobacco Free Initiative. This document contains a more extensive list of elements that would improve any warning system. ${ }^{11}$

Contributors GM conceptualised and wrote this commentary.

Funding The authors have not declared a specific grant for this research from any funding agency in the public, commercial or not-for-profit sectors.

Competing interests None declared.

Patient consent for publication Not required.

Provenance and peer review Not commissioned; externally peer reviewed.

(c) Author(s) (or their employer(s)) 2021. No commercial re-use. See rights and permissions. Published by BMJ.

\section{D) Check for updates}

To cite Mahood G. Tob Control 2021:30:1-3. Published Online First 3 December 2020
Tob Control 2021:30:1-3.

doi:10.1136/tobaccocontrol-2020-055961

\section{ORCID iD}

Garfield Mahood http://orcid.org/0000-0002-7656086X

\section{REFERENCES}

1 Cigarette labeling and health warning requirements, 2020. FDA. Available: https://www.fda.gov/tobaccoproducts/labeling-and-warning-statements-tobaccoproducts/cigarette-labeling-and-health-warningrequirements [Accessed October 18, 2020]

2 Brandt AM. The Cigarette Century: The Rise, Fall and Deadly Persistence of the Product that Defined America. New York: Basic Books, 2007: 254.

3 Warning: Your kids are sick of your smoking. second hand smoke causes more frequent and severe asthmatic attacks in children. Available: https:// tobaccolabels.s3.ca-central-1.amazonaws.com/ uploads/health_warnings/Canada/lmages/2012\% 20Warnings/Cigarettes/Canada\%202012\%20ETS\% 20children $\% 20-\% 20$ lived $\% 20$ experience, $\%$ 20asthma\%20-\%20eng.jpg [Accessed October 18, 2020].

4 Mahood G. Tobacco Industry Denormalization: Telling the truth about the tobacco industry's role in the tobacco epidemic", Toronto: Non-Smokers' Rights Association, 2004, 1-8. Available: https://nsra-adnf. ca/key-issue/tobacco-industry-denormalization-tellingthe-truth-about-the-tobacco-industrys-role-in-thetobacco-epidemicl [Accessed October 18, 2020].
5 Malone RE, Grundy Q, Bero LA. Tobacco industry denormalisation as a tobacco control intervention: a review. Tob Control 2012;21:162-70.

6 Ling PM, Neilands TB, Glantz SA. The effect of support for action against the tobacco industry on smoking among young adults. Am J Public Health 2007:97:1449-56.

7 Mahood G. Canadian tobacco package warning system. Tob Control 1995;4:10-14.

8 Tobacco Institute, Roper Organization. A Study of Public Attitudes Toward Cigarette Smoking and the Tobacco Industry in 1978. Roper Organization, 1978.

9 United States District Court for the District of Columbia. United States of America et al, V. Philip Morris USA Inc., et al. final opinion: August 17, 2006. civil action No. 99-2496 (GK): 1,522-1,524 Available: https://www.publichealthlawcenter.org/ sites/default/files/resources/doj-final-opinion.pdf

10 Mahood G. Briefing note for the Canadian media: "What the government didn't tell you about Canada's new tobacco warnings", Non-Smokers' Rights Association, Toronto, July 16, 2012. Available: http:// justiceontobaccofraud.ca/downloads/en/What $\%$ 20the $\% 20$ government $\% 20$ didn $\% 27 t \% 20$ tell\% 20 you $\% 20$ about $\% 20$ Canada $\% 275 \% 20$ new $\%$ 20 tobacco\%20warnings.pdf

11 Mahood G. Canada's Tobacco Package Label or Warning System: 'Telling the Truth' about Tobacco Product Risks. World Health Organization, 2003. Available: https://www.who.int/tobacco/training/ success_stories/en/best_practices_canada_package. pdf [Accessed May 16, 2020]. 